KAJA KAŹMIERSKA

니

\title{
PAMIĘTNIK IMIGRANTA JAKO PRZEDMIOT ANALIZY W CHŁOPIE POLSKIM W EUROPIE I AMERYCE. REFLEKSJA W STULECIE WYDANIA
}

ABSTRACT. Kaja Kaźmierska, Pamiętnik imigranta jako przedmiot analizy w "Chłopie polskim w Europie iAmeryce". Refleksja w stulecie wydania [An immigrant's diary as a subject of analysis in Polish Peasant in Europe and America. Reflection on the Centennial of the Edition] edited by M. Nowak " Człowiek i Społeczeństwo" vol. XLVII: „Chłop polski w Europie i Ameryce” po stu latach [Polish peasant in Europe and America after one hundred years], Poznań 2019, pp. 39-56, Adam Mickiewicz University. Faculty of Social Sciences Press. ISSN 0239-3271.

The subject of the article is a reflection on the significance of the study Polish Peasant in Europe and America by W.I. Thomas and F. Znaniecki as a canonical text in the field of qualitative and, especially, biographical research. Referring to the criticism carried out by Herbert Blumer in 1939, it is an attempt to present to what extent the critical arguments remain valid nowadays and to what extent they can be verified by taking into account the contemporary state of the biographical method. The aim of the text is also to show the tension between the pioneering contribution of the authors to social research and the declarations contained in the Methodological Note and their implementation concerning the empirical material, namely the Memoirs of an Immigrant (Władek Wiśniewski) published in Volume III.

Kaja Kaźmierska, Uniwersytet Łódzki, Katedra Socjologii Kultury, ul. Rewolucji 1905 r. nr 41, 90-214 Łódź, e-mail: kaja.kazmierska@uni.lodz.pl 


\section{Wprowadzenie}

William I. Thomas i Florian Znaniecki, publikując w 1918 r. pierwszy z pięciu tomów monografii The Polish Peasant in Europe and America ${ }^{1}$, stworzyli dzieło, które dziś uznać można za kanoniczny tekst w dziedzinie badań jakościowych, a zwłaszcza biograficznych. Zarazem, ze współczesnej perspektywy, bogatsi o nowe podejścia analityczne, reprezentujący inną wrażliwość metodologiczną i aksjologiczną, możemy starać się spojrzeć na tę pracę w kilku planach: po pierwsze, analizując relację między zaprezentowanymi przez autorów założeniami a podjętą przez nich analizą materiałów empirycznych, po drugie, pokazując niedoskonałości tej analizy, po trzecie, charakteryzując wkład dzieła w ówczesny i dalszy dorobek socjologii. Rzecz jasna, w jednym artykule trudno jest skomentować te kwestie w odniesieniu do wszystkich aspektów, wątków teoretycznych czy metodologicznych pracy. Wybieram więc jeden, najbliższy mi problem związany z uznaniem (słusznym) Chłopa polskiego... za dzieło dające początek rozwojowi metody biograficznej. Trzeba zarazem podkreślić, że podstawowym celem Thomasa i Znanieckiego nie była prezentacja materiałów autobiograficznych czy też losów ich autorów w ramach metody badań biograficznych jako takich, lecz analiza procesu zmiany społecznej, na którą składały się kategorie: wartości i postawy, osobowość społeczna oraz organizacja, dezorganizacja i reorganizacja. W odniesieniu do całości przyjętego zamierzenia Jan Szczepański we wstępie do wydania polskiego pisał, że z biegiem czasu nabrało ono dodatkowych i nowych wartości, czy nawet nowych znaczeń społecznych, gdy się zaś ukazało po raz pierwszy, ,była to wielka monografia socjologiczna, wnosząca nowe pomysły metodologiczne, nowe materiały, nowe koncepcje teoretyczne, zwrot w dziejach socjologii empirycznej” (Szczepański, 1976: 30). Zarazem jednak zauważył, że autorzy „nie zastanawiali się szczegółowo nad technikami opracowania materiału”. Ten brak pogłębionej refleksji metodologicznej, jak będę się starała pokazać w dalszej części tekstu, nie przeszkodził widzieć w Chłopie polskim... pierwszej pracy socjologicznej opartej na analizie materiałów autobiograficznych, zapoczątkowującej w obrębie szkoły chicagowskiej badania wykorzystujące podejście biograficzne. Powstało tam ponad dwadzieścia

${ }^{1}$ W roku 1918 ukazały się tomy pierwszy i drugi, w 1919 r. tom trzeci, w 1920 r. tomy czwarty i piąty. Polskie tłumaczenie zostało wydane w roku 1976. 
studiów monograficznych z uwzględnieniem takich materiałów. Wśród monografii szczególnie bliskich badaczom biograficznym można wskazać m.in. Clifforda R. Shawa The Jack-Roller: A Delinquent boy's own story (1930). Należy też podkreślić, że dzieło Thomasa i Znanieckiego stało się źródłem inspiracji dla rozwoju socjologii w Polsce (szczególne zasługi trzeba tu przypisać samemu Znanieckiemu) oraz metody biograficznej w socjologii polskiej, zwłaszcza opartej na materiałach autobiograficznych pozyskiwanych w drodze konkursów na pamiętniki (por. Chałasiński, 1976: 24). „Pamiętnikarstwo inspirowane”, czyli gromadzenie pamiętników przedstawicieli różnych grup społecznych w drodze konkursów, istotnie stanowi polską specyfikę i jest znaczącym wkładem do badań biograficznych. Stąd metoda biograficzna w obcojęzycznych omówieniach polskiej i światowej socjologii z lat pięćdziesiątych-siedemdziesiątych XX w. była niekiedy nazywana metodą polską (Dulczewski, 1975: 83).

Cel, jaki stawiam sobie w niniejszym artykule, to spojrzenie na dzieło wyłącznie z perspektywy metody biograficznej i pokazanie, w jakiej mierze autorzy mogli uniknąć pewnych błędów, analizując materiał, a w jakim stopniu ich popełnienie było efektem ówczesnego spojrzenia na materiał empiryczny i w ogóle na sposób uprawiania nauk społecznych, co z czasem stało się impulsem do stawiania dalszych pytań i wzbogacania refleksji metodologicznej i teoretycznej.

\section{Krytyka Herberta Blumera a perspektywa współczesna}

W 1939 r., a więc dwadzieścia jeden lat po ukazaniu się pierwszego tomu The Polish Peasant..., Herbert Blumer poddał dzieło dość ostrej krytyce. Odnosiła się ona do wszystkich aspektów pracy: założeń teoretycznych i ich operacjonalizacji w przedstawionym czytelnikowi materiale, zastosowanych pojęć, jakości zebranego materiału ze szczegółową jego charakterystyką w odniesieniu do listów, historii życia, innych dokumentów. Tutaj przywołam jedynie krytykę dotyczącą pisanej autobiografii Władka Wiśniewskiego, która w publikacji nosi tytuł Pamiętnik imigranta i zawarta jest w tomie trzecim.

Komentując w części Life Histories as Human Documents (Blumer 1939: 39-47) przedstawienie autobiografii jako materiału empirycznego, Blumer zgadza się z autorami, że ten typ danych umożliwia wgląd w jednostkową perspektywę aktora społecznego. Jednocześnie zauważa, iż nie zostają spełnione żadne z przedstawionych przez Thomasa i Znanieckiego we Wstępie 
do tomu trzeciego założeń. Autorzy pisali: „Możemy z całą pewnością powiedzieć, że osobiste materiały życiorysowe, możliwie jak najpełniejsze, stanowią typ d o s $\mathrm{k}$ o $\mathrm{n}$ a ł y materiału socjologicznego; jeśli socjologia musi posługiwać się innymi materiałami, to tylko wskutek praktycznych trudności, jakie przedstawia zgromadzenie dostatecznej ilości takich materiałów, niezbędnych dla wszystkich problemów socjologicznych oraz wskutek ogromnej pracy, jakiej wymaga dokładna analiza wszystkich materiałów autobiograficznych, niezbędnych dla opisania grupy społecznej” (Thomas i Znaniecki, 1976, t. 3: 8). Ta jednoznaczna deklaracja, z którą, reprezentując perspektywę badań biograficznych, trudno się nie zgodzić, została uszczegółowiona, gdy Thomas i Znaniecki stwierdzają, że autobiografia umożliwia badanie relacji między wartościami a postawą, obserwację abstrakcyjnych praw społecznych, pokazuje procesualność postaw i ich zmianę poprzez serie doświadczeń, a co się z tym wiąże - procesualność ludzkiego życia poprzez poznanie natury osobowości społecznej i charakterystykę jej typu (Thomas i Znaniecki, 1976, t. 3: 8). Tak więc życie społeczne powinno być postrzegane jako interakcja między organizacją społeczną (tym, co obiektywne) a doświadczeniem indywidualnym (tym, co subiektywne), przy czym wgląd w nie dostarczają socjologii materiały biograficzne.

Według Blumera przedstawiona przez Thomasa i Znanieckiego analiza autobiografii Władka Wiśniewskiego nie dała możliwości zbadania ani relacji między wartościami a postawą, ani obserwacji abstrakcyjnych praw społecznych, ani procesu przemiany postaw i opisu relacji między organizacją społeczną a doświadczeniem indywidualnym (Blumer, 1939: 43). I nie chodzi o ułomność samego materiału (chociaż Blumer i tu miał krytyczne uwagi, o czym za chwilę), lecz o słuszny zarzut braku umocowania tez autorów w materiale empirycznym - przeciwnie, wpisują oni prezentowaną opowieść autobiograficzną w przyjęte wcześniej założenia i im podporządkowują interpretację. Odchodząc od perspektywy indukcyjnej, wręcz lekceważą potencjał analityczny autobiografii, powielają też w dużej mierze wyróżnione w Nocie metodologicznej błędy socjologii zdroworozsądkowej. W odniesieniu do rozważonego tu podejścia do analizy autobiografii i braku relacji między perspektywą teoretyczną a materiałem empirycznym, można wskazać zwłaszcza dwa błędy: „Domniemanie, że znamy rzeczywistość społeczną, ponieważ w niej żyjemy, i że na podstawie naszego doświadczenia możemy przyjmować za pewnik pewne stany rzeczy i stosunki społeczne” (Thomas i Znaniecki, 1976, t. 1: 43). Opisany przez autorów jako trzeci błąd socjologii zdroworozsądkowej to „milcząco przyjęte założenie, że każda grupa społecznych faktów może być rozważana 
teoretycznie i praktycznie w arbitralnej izolacji od reszty danego społeczeństwa” (Thomas i Znaniecki, 1976, t. 1: 47). Do wątku tego jeszcze powrócę.

Druga grupa zarzutów dotyczy jakości materiału oraz jego potencjału analitycznego. Blumer nie stroni tu od najczęściej stawianych materiałom biograficznym, w tym zwłaszcza autobiografiom (pisanym bądź opowiadanym), zarzutów związanych z kryteriami reprezentatywności, trafności (adequacy), wiarygodności oraz prawomocności ich interpretacji (Blumer, 1939: 44). Ostatni z wymienionych zarzutów jest w zasadzie powtórzeniem wcześniej pokazanych wątpliwości dotyczących procesu interpretacji materiału empirycznego - obok zatem stwierdzenia, że autorzy, wbrew deklaracjom, porzucają indukcyjne podejście badawcze, a w zasadzie nie podejmują go, Blumer pokazuje również, że zabieg „ilustracyjny” w analizie poszczególnych elementów autobiografii poprzez podporządkowanie ich wcześniejszej, gotowej teorii (np. dotyczącej typów osobowości) jest mało przekonujący. Zawarte w przypisach wyjaśnienia konkretnych doświadczeń także trudne są do zaakceptowania, gdyż czytelnik nie widzi, aby teoretyczne eksplikacje faktycznie przystawały do analizowanych fragmentów autobiografii, co postaram się pokazać w następnej części tekstu.

Warto chwilę uwagi poświęcić zarzutom dotyczącym reprezentatywności, trafności i wiarygodności, gdyż, jak już wspomniałam, należą one do stałego repertuaru argumentów krytycznych wobec metody biograficznej. Trzeba przy tym podkreślić, że jest to krytyka prowadzona „z zewnątrz”, czyli przez niestosujących tej metody sceptyków, oraz podnoszona przez samych badaczy biograficznych, którzy często (zapewne też pod presją „zewnętrznej” perspektywy) zadają sobie podobne pytania.

Przedstawiając wątpliwości Blumera, skomentuję je zatem, uwzględniając dzisiejszą perspektywę. W odniesieniu do kryterium reprezentatywności Blumer ma na myśli nie tyle pytanie zadawane w paradygmacie normatywnym, zdominowanym przez myślenie pozytywistyczne, ile problem traktowania biografii jako egzemplifikacji danych procesów społecznych. Przypomnijmy, że pytanie stawiane z perspektywy pozytywistycznej, uznającej przede wszystkim moc teoretyczną reprezentatywności statystycznej, zyskało prawomocność w latach późniejszych. Po doświadczeniach szkoły chicagowskiej z lat trzydziestych i czterdziestych ubiegłego wieku socjologię światową, a zwłaszcza amerykańską, zdominował bowiem strukturalizm funkcjonalny oraz metody ilościowe uznane wówczas za bardziej naukowe (Helling, 1990: 15). Blumer, publikując swoją krytykę w 1939 r., raczej nie mógł brać pod uwagę takiej perspektywy i zapewne niechętnie by się z nią identyfikował. Tak więc pyta on o typowość autobiografii Władka 
Wiśniewskiego w odniesieniu do deklaracji samych autorów, którzy uznają go, co prawda, już nie za typowego chłopa, ale jednak za typowy przypadek biografii ukazującej dezintegrujący wpływ, jaki ma przejście od starej do nowej formy układu społecznego (Thomas i Znaniecki, 1976, t. 3: 53). Należy zgodzić się z wyrażanymi przez Blumera wątpliwościami. W tym ujęciu zamieszczenie autobiografii Władka Wiśniewskiego w publikacji Chłop polski... jest dość mylące. Thomas i Znaniecki wprawdzie zauważają, że rodzina Władka nie reprezentuje już tej klasy społecznej („Władek i jego rodzina są pochodzenia chłopskiego i są często w kontakcie z chłopami, ale nie należą już do społeczności chłopskiej” (Thomas i Znaniecki, 1976, t. 3: 52)). Pozostając na klasowym pograniczu światów, wchodzi powoli w środowisko miejskie, aspirując do niższej klasy średniej, jednak punktem odniesienia w analizach autorów pozostaje właśnie „chłop polski”, co - jak zobaczymy w kolejnej części rozważań - wyrażone jest expressis verbis w zamieszczonych przez autorów przypisach. Jeśli patrzymy na to z takiej perspektywy, typowość biografii Władka jest wielce problematyczna.

Drugi zarzut Blumera wynika z pytania o to, czy nawet tak szczegółowa opowieść, jaką jest autobiografia Władka, daje możliwość prześledzenia procesów społecznych, przemian osobowości autora opowieści o życiu. Wątpliwość ta jest, moim zdaniem, efektem przyjętego przez Thomasa i Znanieckiego, a opisanego wyżej sposobu analizy, który opiera się nie na tekście, czy choćby treści autobiografii jako takiej, ale na teoretycznych konstruktach przyjętych w pracy. Patrząc na autobiografię Władka ze współczesnej perspektywy, traktować ją można jako bardzo bogaty materiał empiryczny - opowieść o życiu umożliwiającą charakterystykę wielu procesów i zjawisk społecznych.

Kolejny zarzut, bardzo często stawiany relacjom autobiograficznym, dotyczy wiarygodności. Blumer nie stroni tu od najczęściej zadawanych w tym kontekście pytań: czy autor swojej biografii wystarczająco dobrze pamięta fakty i okoliczności - czy zatem jego opowieść jest „rzeczywistym” odbiciem rzeczywistości społecznej? Czy pisze/mówi prawdę?² Takie postawienie sprawy przez Blumera można określić jako perspektywę realistyczną, zakładającą, że rzeczywistość społeczno-historyczna ma charakter ponadjednostkowy i dana jest ludziom w ich doświadczeniu biograficznym, poprzez które dokonują oni jej subiektywnej interpretacji. Tymczasem,

2 Sami autorzy piszą, że starali się weryfikować wiarygodność opowieści Władka, posiłkując się np. rodzinną korespondencją, i konfrontacja ta wypadła dla autora pamiętnika pozytywnie. 
zwłaszcza przy uwzględnieniu współczesnego spojrzenia na opowieść autobiograficzną, kwestie prawdomówności czy zgodności z faktami, choć ich znaczenie nie jest unieważnione, stają się często drugoplanowe wobec sposobu budowania opowieści i prezentacji siebie. Innymi słowy, chodzi o traktowanie „biografii jako środka” i/lub „,biografii jako tematu”. W pierwszym przypadku na plan pierwszy wysuwa się pytanie „co?”, zmierzające do zebrania informacji biograficznych służących do udzielenia odpowiedzi na typowe pytania socjologiczne (np. o strukturę czy ruchliwość społeczną). W drugim przypadku biografię traktuje się jako zagadnienie samo w sobie, zainteresowanie badacza skierowane jest na strukturę (narracji/biografii) i wyrażone w pytaniu, ,jak?” konstruowana jest narracja, w jaki sposób interakcyjne warunki jej wytwarzania kształtują opowieść, jak dokonuje się biograficzna rekonstrukcja przebiegu życia itp. (Helling, 1990: 16). Pamiętnik Władka Wiśniewskiego z pewnością jest bogatym i rzetelnym zasobem empirycznym dla odpowiedzi na pytanie „co?”. Umożliwia również analizę tego, „jak?” snuta jest opowieść i dokonywana autoprezentacja. To przekonanie można podbudować pozytywną oceną jakości narracyjnej tekstu (chociaż, jak wskazałam, Blumer ma co do tego wątpliwości). Chodzi tu o dużą dozę spontaniczności opowieści Władka Wiśniewskiego, wynikającej z tempa pisania autobiografii (co zapewne motywowane było chęcią jak najszybszego otrzymania gratyfikacji) ${ }^{3}$. Fakt ów w dużej mierze zapewniał spontaniczność opowieści, rzecz jasna, rozumianą nie tyle jako narracja swobodna, ile polegająca na nieopracowywanym, bo na to nie było czasu, spisywaniu swoich dziejów. Dodatkowo można przywołać stosowane dziś kryteria związane z oceną narracji biograficznej poprzez przywoływanie epizodów biograficznych, odtwarzanie dialogów, stosowanie mowy niezależnej itp. Wszystko to znajdujemy w opowieści Władka. Uważam więc, że zarówno w świetle komentarzy Thomasa i Znanieckiego, jak i dzisiejszego stanowiska badaczy biograficznych wątpliwości Blumera są tu przesadzone.

Dodatkowym punktem odniesienia mogłoby być porównanie autobiografii Władka z innymi narracjami z tego okresu. Szczęśliwie dysponujemy taką możliwością. Chodzi o Życiorys własny przestępcy autorstwa Urke Nachalnika - autobiografię powstałą w duchu szkoły chicagowskiej, opublikowaną po raz pierwszy w 1933 r. W dużej mierze, jeśli wziąć pod uwagę jej formę, przypomina ona opowieść Władka Wiśniewskiego. Nie chodzi tu przy

${ }^{3}$ Władek Wiśniewski, zgodnie z deklaracją badaczy, otrzymał wynagrodzenie za swój manuskrypt i będąc w trudnej sytuacji finansowej, a właściwie bez środków do życia, pisanie pamiętnika traktował jako źródło zarobku. 
tym o treść doświadczeń biograficznych (choć i tu odnaleźć można pewne podobieństwa, np. obaj byli piekarzami, mieli bogate życie erotyczne, bardzo wcześnie przeszli inicjację seksualną itd.), ale o sposób budowania narracji. Można by pokusić się o eksperyment wymieszania tych opowieści przez przeniesienie pewnych fragmentów z jednej do drugiej - myślę, że czytelnik mógłby nie zauważyć różnicy. Wynika to z faktu, że obydwa życiorysy są tekstami kultury przynależnymi tej samej epoce, podobnemu środowisku, a ich autorzy cechowali się dość podobnym temperamentem i zdolnościami literackimi. Dla przykładu zamieszczam dwa fragmenty odnoszące się do ich relacji z kobietami. Z konieczności stanowią one jedynie próbki narracji, dotyczą podobnej sytuacji, tj. jednej z wielu opisanych przygodnych relacji, w perspektywie całej opowieści niewiele znaczących przygód erotycznych.

Całą noc nie mogłem zasnąć, kusiła mnie ta nowa znajomość z Elcią. Nie była ona ładna, ale miała coś w sobie, co mnie pociągało, postanowiłem rano przypuścić nowy atak do jej cnoty. [...] Myślę, że kobieta niczym nie pociągnie mężczyzny jak oporem. Kobieta łatwa do ustępstwa traci zupełnie na wartości w oczach mężczyzny, choćby nawet w ogóle oddała się po raz pierwszy w życiu. [...] Drugi wieczór znów przyszła i na moje nalegania ustąpiła. Oddała mi się ze łzami w oczach dopiero na moje przysięgi, że gdy przekonam się, że jest niewinna, to jej nie będę wcale ruszał. Uwierzyła mi. Jednak tej próby nie wytrzymałem i cnota jej pękła na niewinnym drewnianym kufrze... (Nachalnik, 1989: 265-266).

W końcu Mania upiła się z kretesem i nie mogłem wracać, póki była w takim stanie. [...] Wziąłem pokój z jednym łóżkiem i przy pomocy kelnera przeniosłem do niego Manię. [...] Zacząłem ją rozbierać. Trudno wyrazić na piśmie, co się we mnie działo w miarę, jak dobierałem się bliżej i bliżej do jej ciepłego ciała. W końcu zacząłem okrywać ją pocałunkami. Złożyłem ją na łóżku i wypiłem pół butelki wody sodowej, bo nie miałem odwagi zgwałcić nieprzytomnej dziewczyny. [...] [rano] Uspokajałem ją, mówiąc, że mam gotowy plan, który wybawi ją z kłopotu, i przysiadłem się bliżej koło niej. Zaraz jednak okryła się cała kołdrą. Zacząłem ściągać kołdrę z jej twarzy, żeby ją całować, i gdyby na to pozwoliła, skończyłoby się na pocałunkach. Ale dlatego, że mi się sprzeciwiała, robiłem się jurniejszy. W końcu nie mogłem już powstrzymać się, rzuciłem się z całą gwałtownością na nią jak wilk na owcę i chociaż próbowała się bronić i groziła, że będzie krzyczeć, wszystko zdało się na nic (Thomas i Znaniecki, 1976, t. 3: 150).

Zdecydowałam się przytoczyć te fragmenty nie po to, aby epatować opisami przygód erotycznych obu autorów, lecz by pokazać łudzące podobieństwo formy i stylu opisu, w których role i racjonalizacje postępowania są tak samo rozpisane. Krótko mówiąc, wahania Blumera co do jakości opowieści 
Władka Wiśniewskiego mierzone rzetelnością i wiarygodnością opisów uznałabym za mocno przesadzone.

Inną sprawą, na którą Blumer nie zwraca uwagi, jest kwestia oceny potencjału analitycznego tekstu autobiografii - zwłaszcza jeśli brać pod uwagę dzisiejsze analityczne możliwości pracy nad tekstem. Pytania o wiarygodność dotyczyły tekstu przetłumaczonego z polskiego na angielski ${ }^{4}$. Trudność ta niewątpliwie multiplikuje się w polskim tłumaczeniu dzieła, w którym mamy do uczynienia z pamiętnikiem przetłumaczonym z języka polskiego na angielski i ponownie na polski, bez możliwości sięgnięcia do oryginału, którym byłby polski rękopis pamiętnika.

Kolejnym ważnym wątkiem jest kwestia tego, że bezpośrednia ${ }^{5}$ analiza autobiografii Władka Wiśniewskiego zawarta jest w przypisach. Pojawiają się one z różną częstotliwością, są mniej lub bardziej rozbudowane. Taki sposób analitycznego komentowania tekstu odnaleźć można w kolejnych pracach należących do szkoły chicagowskiej, np. w książkach Clifforda Shawa The Jack-Roller czy The Natural History of a Delinquent Career. W przypadku Pamiętnika imigranta przypisy w większości przypadków stanowią rodzaj komentarzy - do fragmentów opowieści, które wydają się autorom szczególnie znaczące. Przy czym nie dotyczą one struktury tekstu, sposobu budowania opowieści, ale przedstawianych faktów, opisów zdarzeń, zachowań Władka. Jeśli trudno czynić uwagi krytyczne w odniesieniu do braku wątków analitycznych opartych na dociekaniach, jak tworzona jest opowieść - jak zauważa Marek Czyżewski (1992: 95-96), Thomas i Znaniecki, a także inni autorzy klasycznych monografii chicagowskich opartych na materiałach biograficznych, nie dysponowali technikami analizy związanymi z nowszymi nurtami socjologii interpretatywnej, a więc zaczerpniętymi z analizy konwersacyjnej czy lingwistycznej analizy tekstu - to trudno uznać wiele z zawartych w przypisach konstatacji za uprawnione analitycznie. Można wyróżnić dwie przyczyny tych wątpliwości: po pierwsze, tak jak argumentowałam wyżej, wynikać mogą one z ówczesnego stanu wiedzy oraz stanu swoistej wrażliwości społecznej (w wielu miejscach pojawiają się sformułowania, które dzisiaj uznać należy np. za niepoprawne politycznie,

${ }^{4}$ Władek Wiśniewski napisał autobiografię po polsku; została ona następnie przetłumaczona na język angielski w pierwszym wydaniu The Polish Peasant... i ponownie przetłumaczona na język polski przy publikacji polskiej wersji dzieła.

${ }^{5}$ Przez określenie „bezpośrednio” rozumiem pracę nad tekstem autobiografii sprzężoną z opowieścią Władka. Wątki analityczne odnoszące się do tego materiału w wymiarze ogólnym, jako swoistego przypadku, znaleźć można we Wstępie i Wnioskach do tomu trzeciego, w którym znajduje się Pamiętnik imigranta. 
czy wręcz związane z językiem uprzedzeń); po drugie, i to uczynić należy centralnym punktem krytyki, komentarze te nie są ugruntowane w tekście opowieści, są raczej podporządkowanymi wizji autorów eksplikacjami. Co ciekawe, Blumer nie zwraca w ogóle uwagi na ten pierwszy aspekt, skupiając swoją krytykę na kwestii narzucania przez autorów swojej perspektywy teoretycznej na empiryczną. W kolejnej części tekstu odniosę się do obydwu wyrażonych powyżej wątpliwości.

\section{Między opowieścią autobiograficzną a analizą - przykłady interpretacji polemicznych}

Odwołajmy się zaledwie do trzech z wielu przykładów przypisów zamieszczonych w autobiografii. Pierwszym z nich jest przypis 25 na stronie 72 . Dotyczy on sytuacji, w której dwunastoletni Władek przeżywa inicjację seksualną za sprawą osiemnastoletniej kobiety, która wykorzystuje jego naiwność i wprowadza go w świat doznań erotycznych. Władek traktuje je jako rodzaj ekscytującej zabawy i chce ją jak najczęściej kontynuować. Kiedy dziewczyna odmawia (wykorzystanie seksualne chłopca traktuje jako mało znaczący epizod), Władek grozi wydaniem tajemnicy. Autorzy w ten sposób komentują opisaną sytuację:

Postawa szantażu rozwinięta od wieku dziecięcego. Instynkt pożądania seksualnego u chłopa, sytuacja społeczna, inicjatywa dziewczyny, normy opinii publicznej i zależność dziewczyny od tej opinii: oto dane, z których wynika całkiem oczywiście zachowanie się Władka (Thomas i Znaniecki, 1976, t. 3: 72).

W przedstawionym komentarzu nie ma odniesień do sposobu inicjacji seksualnej, który dzisiaj nazwany byłby po prostu czynem pedofilii. Autorzy w ogóle nie rozważają anormatywności tej sytuacji, nie biorą pod uwagę, że niedojrzałość emocjonalna dwunastolatka połączona ze zbyt wczesną inicjacją seksualną doprowadza do traktowania aktu seksualnego jako szczególnego typu zabawy - ma to też odzwierciedlenie w języku: Władek sytuacje te określa mianem „figlowania”. Te okoliczności nie są brane pod uwagę, kiedy autorzy uznają niemalże wrodzoną skłonność Władka do szantażu. Można spróbować wytłumaczyć ten sposób interpretacji brakiem ówczesnej wiedzy na temat np. psychologii rozwojowej dziecka. Natomiast zupełnie problematyczne jest potraktowanie „instynktu pożądania seksualnego u chłopa” jako jednego z czynników regulujących zachowanie dwunastoletniego Władka. 
Passus ten ukazuje wyraźnie interpretację przeżyć autora autobiografii nie w kontekście jego osobistych doświadczeń, lecz przez pryzmat przyjętych przez Thomasa i Znanieckiego interpretacji zachowań. Tymczasem w rozważaniach teoretycznych znajdujemy tak kluczową, zwłaszcza dla Thomasa, definicję sytuacji. Warto na marginesie zauważyć, że pojęcie sytuacji wprowadzone w Chłopie polskim... pojawia się również w innych pracach Thomasa, np. w The Unadjusted Girl. Autor używa zamiennie określeń „definicja sytuacji” i „schematy postępowania”. To właśnie praca The Unadjusted Girl cytowana jest zazwyczaj w odniesieniu do szerokiego w niej zastosowania terminu „definicja sytuacji”. „Jeśli ludzie definiują sytuacje jako rzeczywiste, są one rzeczywiste w swoich konsekwencjach” (Thomas, 1923: 584, za: Hałas, 1983: 37). W odniesieniu do rozważanego przypisu, a także następnego, przytoczonego poniżej, takie rozumienie sytuacji nie znajduje zastosowania. Problem tkwi w odmiennym zdefiniowaniu epizodu seksualnego przez osiemnastoletnią dziewczynę i dwunastoletniego chłopca. Przykład ten wzmacnia zasadność krytyki Blumera odnośnie do chłopskiej typowości przypadku. Kategoria przynależności klasowej staje się tu podstawową ramą odniesienia dla interpretacji zachowań. Co więcej, sformułowanie „instynkt pożądania seksualnego u chłopa” jest sprzeczne z deklaracjami autorów dystansujących się od naturalistycznych konotacji. Skądinąd często jako jeden z walorów pracy podkreśla się właśnie fakt wyraźnego odejścia od naturalistycznego, popularnego wówczas oglądu rzeczywistości. Przykład ten pokazuje (zauważone też przez Blumera) napięcie między zawartymi w Nocie metodologicznej założeniami a zoperacjonalizowaniem ich w podejściu analitycznym. Widać tu ponadto wyraźnie, że autorzy, narzucając swoją wizję rzeczywistości, padli ofiarą jednego ze wspomnianych błędów socjologii zdroworozsądkowej, czyli domniemaniu, „że znamy rzeczywistość społeczną, ponieważ w niej żyjemy”.

Drugi przypis jest równie problematyczny. Dotyczy sytuacji, w której Władek znajduje się u kolejnego mistrza piekarskiego jako czeladnik. Nie może znieść stosowanej tam przemocy: bicia, poniżania, wykorzystywania i zmuszania do pracy ponad możliwości kilkunastoletniego chłopca. Nie znajduje wsparcia rodziców i rodzeństwa, którzy jego skargi traktują jako oznaki lenistwa, wymigiwania się od pracy i lekceważenia obowiązków. $\mathrm{W}$ tej sytuacji planuje desperacki czyn obcięcia sobie palca u ręki. Zaopatruje się w nóż, ale w końcu brakuje mu odwagi, aby to uczynić. Thomas i Znaniecki opatrują ten epizod następującym przypisem:

Istota rzeczy leży w tym: w przykrej sytuacji chłopiec pragnie pomocy społecznej - próbuje okaleczyć się, aby przez cierpienie wzbudzić litość. 
Typowy to rys osobnika słabego, który chce uniknąć przykrej sytuacji, względnie zmienić ją na przyjemną, opierając się na interwencji innych, a nie na własnym działaniu: zjawisko nagminne wśród histerycznych kobiet (Thomas i Znaniecki, 1976, t. 3: 85).

Biorąc pod uwagę zamieszczony w przypisie komentarz, odnoszę się do polskiej wersji tekstu. Niezależnie bowiem od niuansów translacyjnych Władek zostaje tu zdiagnozowany jako „słaby osobnik”, histerycznie reagujący na trudne sytuacje życiowe. Dodatkowego kolorytu tej ocenie dodaje fakt porównania jego zachowania z zachowaniem „histerycznych kobiet”. Autorzy nie wyjaśniają dalej, co rozumieją przez to porównanie. Można więc przypuszczać, iż zakładają, że ich intencje zostaną zrozumiane przez czytelnika. Odwołują się zatem do niejako „wiedzy podręcznej”, w tym przypadku opartej na negatywnym stereotypie wpisanym w aspekt genderowy. Z pewnością współcześnie, analizując rzeczywistość społeczną, trudno byłoby w publikacji naukowej czerpać z takiego zasobu. Wracając do doświadczeń kilkunastoletniego chłopca, Thomas i Znaniecki, co prawda, zwłaszcza w oryginalnej wersji angielskiej, używają określenia „cierpienie”, to jednak mają wątpliwości, czy jest ono szczere czy udawane, tzn. czy nie jest tylko strategią biograficzną dla wyjścia z sytuacji zdefiniowanej przez Władka jako bolesna (w tłumaczeniu polskim jako „przykra”). W moim odczuciu współczesny czytelnik, zwłaszcza socjolog, pedagog czy psycholog, zinterpretuje te doświadczenia odmiennie. Ja opiszę je, używając języka analitycznego, wprowadzonego przez Fritza Schützego w celu charakterystyki doświadczeń biograficznych. Kilkunastoletni chłopiec doświadcza trajektorii cierpienia - nie jest w stanie znieść trudów pracy, bicia, poniżania i awantur ciągle pijanego majstra, którego zachowanie bywa nieobliczalne. Wobec braku reakcji rodziny, zwłaszcza ojca, który nie chce poprawić jego sytuacji życiowej przez zmianę miejsca, w którym chłopiec mógłby się uczyć zawodu, doświadcza sytuacji usidlenia przez utratę kontroli nad swoim życiem (Schütze, 2012), co prowadzi go do niezrealizowanej decyzji o samookaleczeniu.

${ }^{6}$ Warto przy okazji zwrócić uwagę na różnice interpretacyjne, które mogą wynikać $\mathrm{z}$ tłumaczenia the Polish Peasant... na język polski. W oryginalnej wersji angielskiej przypis ten brzmi następująco: „The essential facts is; painful situation - desire for social help - voluntary or pretence of suffering, to attract pity self-infliction or pretence of suffering, to attract pity. Typical for a weak person who tries to escape an unpleasant situation or induce a pleasant one by relying on social interference instead of his own activity, and prevalent in hysterical women”. Chociaż sens tekstu został zachowany, w wersji polskiej jest on jeszcze trudniejszy do przyjęcia z perspektywy współczesnego zasobu wiedzy i wrażliwości społecznej. 
Tymczasem punktem wyjścia dla interpretacji podjętej przez Thomasa i Znanieckiego jest nie tyle perspektywa jednostki, co charakterystyka ówczesnych relacji społecznych. Terminowanie u majstrów było dla młodych chłopców zazwyczaj trudnym doświadczeniem. Najczęściej oczekiwano od nich ciężkiej pracy (często ponad ich fizyczne możliwości), byli bici i poniżani nie tylko przez majstrów, ale też starszych czeladników. Istniało ponadto powszechne społeczne oczekiwanie, że należy przejść tę swoistą inicjację dojrzałościową. W tej perspektywie doświadczenia Władka postrzegane są jako nieumiejętność dostosowania się do wzoru społecznego.

Podstawowym zarzutem, jaki można postawić tej analizie, jest więc, w moim odczuciu, przede wszystkim fakt, że autorzy, deklarując, iż chodzi im o „podmioty świadomie wybierające linię postępowania, a nie po prostu poddające się obowiązującym regułom” (Szacki, 2002: 576), w istocie nie biorą tego pod uwagę. Interesuje ich raczej to, jak rzeczywistość społeczna jest odwzorowywana w doświadczeniu jednostki.

Ostatni przykład to przypis 55 ze strony 99. Thomas i Znaniecki komentują w nim sytuację życiową rodziny D., z którą Władek był zaprzyjaźniony. Stanowiła ona dla niego ważną grupę odniesienia, ponieważ w przeciwieństwie do własnej rodziny był tam akceptowany i lubiany.

\footnotetext{
Żaden chłopiec i żadna dziewczyna z rodziny D. nie osiągnęła sukcesu w życiu. Rodzinie brak dążenia do awansu społecznego, chłopcy nie dążą do wyróżnienia się. Rodzina Władka posiada przynajmniej dążność do pięcia się w górę i stoi u progu powodzenia. Rodzina D. znajduje się poniżej tego progu i jest w stanie odwrotu (Thomas i Znaniecki, 1976, t. 3: 99).
}

Na uwagę zasługują tu dwie kwestie: po pierwsze, miejsce umieszczenia tego przypisu. Znajduje się on we fragmencie opisującym relacje koleżeńskie między synem państwa D. a Władkiem oraz ich relacje damsko-męskie. Trzeba zauważyć, że duża część autobiografii poświęcona jest opisowi mniej lub bardziej znaczących związków Władka i jego kolegów z kobietami. Trudno zdiagnozować, dlaczego taki ocenny przypis znajduje się akurat w tym miejscu. Jedyną wskazówką byłoby odniesienie się do swoistej „hierarchii” relacji. Syn państwa D. związuje się ze służącą, w dodatku „żydowską służącą”, tj. Polką służącą w żydowskiej rodzinie, co, jak wyjaśniają Thomas i Znaniecki we wcześniejszym przypisie, było bardzo poniżające. Można więc wywnioskować, że nie tyle zachowanie wskazujące na dużą swobodę seksualną jest tu wyznacznikiem obniżenia określonych aspiracji życiowych, ile obiekt tych relacji. Drugą ważną kwestią jest zdiagnozowanie przez autorów sytuacji rodziny D. Opis ten przystaje do współczesnej neoliberalnej perspektywy 
postrzegania rzeczywistości. Autorzy oczekują zarówno od rodziny Władka, jak i rodziny D. awansu społecznego. Powracając do zarzutów Blumera, można powiedzieć, że jest to jeden z przykładów, kiedy Thomas i Znaniecki narzucają rzeczywistości społecznej swój sposób kategoryzacji.

\section{Między opowieścią autobiograficzną a analizą - przykłady interpretacji, z którymi można się zgodzić}

W tej części artykułu zamierzam odwołać się krótko do pracy The JackRoller, którą należy, w moim odczuciu, uznać za jedno z wzorcowych opracowań w obrębie szkoły chicagowskiej. Celem tego porównania jest pokazanie z jednej strony roli Chłopa polskiego... w otwarciu określonej perspektywy teoretyczno-analitycznej, z drugiej strony przedstawienie refleksji nad rozwojem takiego sposobu badania rzeczywistości społecznej. Innymi słowy, tego, jak Shaw starał się uniknąć błędów prekursorów tego podejścia.

Ernest Burgess w Dyskusji zamieszczonej w książce The Jack-Roller pokazuje wartość autobiografii w badaniu zjawisk i problemów społecznych. Książka została wydana w roku 1930, a zatem dwanaście lat po ukazaniu się pierwszego tomu The Polish Peasant... i dziewięć lat przed krytyką Blumera. Warto, w moim odczuciu, zwrócić uwagę na tę chronologię. Widzimy tu niejako dwutorowe oddziaływanie publikacji. Z jednej strony wskazuje się na jej słabe punkty, z drugiej kontynuowany jest przyjęty przez Thomasa i Znanieckiego tryb podejścia do materiałów biograficznych jako istotnej perspektywy badawczej. Wyróżnię kilka punktów wspólnych dla obu publikacji w odniesieniu do zainteresowań ich autorów i wskażę różnicę w realizacji tych założeń.

Po pierwsze więc, Burgess, uzasadniając typowość biografii Stanleya jako młodocianego przestępcy, nie ogranicza się wyłącznie do uznania owej typowości, jak to uczynili Thomas i Znaniecki, ale w pięciu punktach argumentuje fakt, że opowieść Jacka Rollera może być uznana za case study dla rozważanej problematyki przestępczości nieletnich (Burgess, 2012: 63-64). Historia życia Stanleya przedstawiona zostaje na tle jego uwikłań środowiskowych i karier przestępczych jego rówieśników opisanych w aktach policyjnych, sądowych czy placówkach wychowawczych. Po drugie, znajdujemy tutaj pogłębioną ocenę wiarygodności autobiografii. Jej kryteria wskazują na źródła inspiracji dla autora życiorysu, potencjalne wpływy, jakim mógł podlegać, oraz oceny prawdomówności. Wszystkie te elementy pokazują, jak ważną kwestią stała się ocena metodologicznej jakości 
materiału biograficznego i jaki typ kryteriów należy tu stosować. Warto zwrócić uwagę, że jednym z nich jest uznanie spontaniczności opowieści:

Być może najlepszą gwarancją wiarygodności dokumentu jest stopień spontaniczności, swobody i uwolnienia (release), jakim cieszy się osoba pisząca czy opowiadająca swoją własną historię. Stanowi to o zasadniczej wyższości historii życia, takich jak ta Stanleya, nad zwykłymi formalnymi dokumentami uzyskiwanymi w wyniku serii ustalonych z góry (cut-and-dried) pytań. Dopóki człowiek opowiada swoją własną historię na swój własny sposób, tak że nosi ona charakter kroniki, obrony, spowiedzi, analizy własnego postępowania, dopóty ujawnia ona oraz zdecydowanie i jasno pokazuje swoją wewnętrzną spójność (Burgess, 2012: 67).

Po trzecie, Burgess zauważa, że próba opisu osobowości Stanleya i przyporządkowania jej konkretnemu typowi ma charakter indukcyjny, a o przypisaniu mu określonej osobowości decyduje nie tylko to, „co” opowiada, ale również sposób, „w jaki” dokonuje autoprezentacji.

Celem odniesień do Jacka Rollera i przedstawienia pokrótce podstawowych wątków Dyskusji autorstwa Burgessa zawartej już w pierwszym wydaniu książki, jest niejako à rebours pokazanie, czego nie zrobili autorzy Chłopa polskiego... Pozostaje postawić pytanie, czy mogli to uczynić. Biorąc pod uwagę przyjęty przez nich sposób uprawiania refleksji teoretycznej w powiązaniu z wymiarem empirycznym - to chyba nie. Zawarte przez autorów w Nocie metodologicznej założenia wprowadziły nowe spojrzenie na relację między tym, co subiektywne i obiektywne, jednak sami autorzy, jak się zdaje, nie potrafili tej relacji skonsumować w swoim dziele. Jednak w roku 1966, a więc niemal pięćdziesiąt lat od ukazania się pierwszego tomu Chłopa polskiego... i trzydzieści sześć lat od publikacji The Jack-Roller, we Wprowadzeniu napisanym specjalnie z okazji wznowienia książki Shawa, Howard Becker napisał:

Historia życia - teoretycznie osadzona w psychologii społecznej George’a Meada, sprawdzona w badawczej praktyce w Chłopie polskim, przekonująco zastosowana przez Ernesta W. Burgessa - cieszyła się ogromną popularnością. Stała się jednym z wielu narzędzi badawczych, które znalazły swoje miejsce w ogólnym programie badawczym tego wydziału [Wydziału Socjologii Uniwersytetu w Chicago - dop. K.K.] (Becker, 2012: 50).

Tak więc dzieło Thomasa i Znanieckiego dało impuls do rozwoju takiego sposobu badania rzeczywistości społecznej, a wskazane przez Blumera, niewątpliwie słusznie, błędy były stopniowo poddawane refleksji i przyczyniały się do rozwoju metody. Znaczącym tego przykładem może być właśnie książka The Jack-Roller wydana już w 1930 r. 


\section{Zakończenie}

W ramach tego fragmentu nie zamierzam podsumowywać przedstawionych wyżej rozważań, ale wprowadzić nowy wątek, który jedynie w ograniczonej formie pojawił się w głównej części tekstu. Czynię to celowo, aby postawione tu pytania czy wyrażone wątpliwości pozostawić otwarte, co powinno dać asumpt do dalszej dyskusji. Chodzi o tak dzisiaj szeroko dyskutowane kwestie etyczne w badaniach społecznych.

Thomas i Znaniecki w ogóle nie podnosili tego problemu. Nie uczynił tego również Blumer, choć poddał dzieło miażdżącej momentami krytyce. A przecież chociażby przedstawione w artykule przypisy (a przykładów takich wypowiedzi jest w pięciotomowym dziele mnóstwo) pokazują wartościujący, niekiedy degradujący, często wręcz uprzedzeniowy język. Thomas i Znaniecki ewidentnie reprezentują dyskurs elit, a mówiąc językiem Alfreda Schütza (1985) - „światłego obywatela”, dla którego perspektywa „człowieka z ulicy” tylko pozornie brana jest pod uwagę jako „eksperta” postrzegania rzeczywistości społecznej. Ekspertami pozostają tu autorzy. Taki sposób podejścia do badanych podmiotów, np. do Władka Wiśniewskiego, można uznać za rodzaj przemocy symbolicznej, brak swoistej wrażliwości czy kompleksowej analizy zjawisk społecznych w odniesieniu do zachowań jednostki może zaś być uwarunkowany ówczesnym stanem wiedzy, np. z zakresu psychologii czy pedagogiki.

Kwestie etyczne związane z przeprowadzeniem badań biograficznych dopiero z czasem zaczęły stanowić przedmiot namysłu badaczy. Ma to miejsce zwłaszcza w ostatnich dekadach, gdy metoda biograficzna zaczęła przeżywać swoisty renesans, a materiałem badawczym stały się przede wszystkim nagrywane wywiady biograficzne i narracyjne. To uwrażliwienie jest z jednej strony podyktowane rozwojem refleksji nad procesem badawczym i wzrastającą w wielu dziedzinach wiedzy, ale też życia, uważnością, czy wręcz empatią, z drugiej zaś zostało wywołane przez toczące się od pewnego czasu dyskusje na temat etycznych aspektów badań i konieczności ich skodyfikowania. Na obu tych polach podstawowe problemy etyczne związane z przeprowadzaniem współczesnych badań biograficznych, opartych przede wszystkim na wywiadach, to: zbudowanie szczególnej relacji zaufania między badaczem a badanym, stworzenie sytuacji symetrycznej (tj. niezdominowanej przez badacza) interakcji, zapewnienie anonimowości i rzetelności, respektowanie opinii badanego związanej z wykorzystaniem 
jego biografii. Te, rzec można progowe, kwestie etyczne zawsze są/powinny być brane pod uwagę przez badacza. Jednocześnie dynamiczne zmiany kulturowe i społeczne ostatnich dwóch dekad stawiają przed badaczami nowe wyzwania o charakterze etycznym. Należy tu wymienić zwłaszcza wymóg archiwizacji i digitalizacji danych, coraz częstsze podejmowanie tzw. reanalizy materiałów, również przez badaczy, którzy nie są autorami danych badań, pojawienie się Internetu, w tym mediów społecznościowych oraz skomercjalizowanie nauki.

Rzecz jasna, Thomas i Znaniecki nie musieli mierzyć się z tymi wyzwaniami. Wprowadzając ten wątek, chcę jednak zwrócić uwagę z jednej strony na pozytywne zmiany związane z większą świadomością metodologiczną i etyczną, z drugiej zaś na krytycznie przeze mnie postrzegany, współczesny trend instytucjonalizacji procesu badawczego i częstej profesjonalizacji etyki (Merrill i West, 2009: 177) polegający na kodyfikacji zachowań badacza i całego procesu badawczego ${ }^{7}$. W odniesieniu do współczesnych standardów moglibyśmy zaryzykować stwierdzenie, że praca Thomasa i Znanieckiego raczej by nie powstała. W tym sensie jest ona signum temporis ówczesnego stylu uprawiania nauk społecznych. Świadczy o tym chociażby fakt, że opisywane przez autorów procesy dezorganizacji społecznej początku XX w. z dzisiejszej perspektywy, wobec współcześnie dynamicznie zachodzących zmian, postrzegać możemy jako opisy ciągle „dobrze się mającego” społeczeństwa tradycyjnego. Zapewne jako badacze społeczni skazani jesteśmy na krytyczny namysł nad rzeczywistością „tu i teraz”, a z takiej perspektywy widzimy ją zawsze jako zmienną i burzącą poprzedni ład.

Wracając jednak do głównego wątku podjętego w zakończeniu, można postawić sobie pytanie: co jest lepsze albo mniej groźne - podejście Thomasa i Znanieckiego nobilitujące perspektywę subiektywnego postrzegania rzeczywistości społecznej przez jednostkę z jednoczesnym dość niedoskonałym jej wykorzystaniem czy dzisiejsze skodyfikowane procedury, które często pod pozorem budowania relacji symetrycznej uprzedmiotawiają badanych i badacza? Czy nauka społeczna jeszcze taką pozostaje, jeśli wyobraźnia socjologiczna, może czasem zawodna, i zwykła umiejętność budowania relacji społecznych zostają skodyfikowane i niejako zobiektywizowane?

Znaniecki i Thomas popełniali błędy, ale można z nimi dzisiaj dyskutować. Współczesny sposób uprawiania nauki ma nas od nich uchronić, ale paradoksalnie zinstytucjonalizowanie tego, co społeczne i negocjowalne z samej natury, może nas sprowadzić na manowce.

\footnotetext{
${ }^{7}$ Szerzej piszę o tym w innym miejscu (Kaźmierska, 2018).
} 


\section{Literatura}

Becker, H.S. (2012). Wprowadzenie. W: K. Kaźmierska (red.), Metoda biograficzna w socjologii. Antologia tekstów (ss. 49-61). Kraków: Zakład Wydawniczy Nomos.

Blumer, H. (1939). An Appraisal of Thomas and Znaniecki's the Polish Peasant in Europe and America. New York: Social Science Research Council.

Burgess, E.W. (2012). Dyskusja. W: K. Kaźmierska (red.), Metoda biograficzna w socjologii. Antologia tekstów (ss. 63-75). Kraków: Zakład Wydawniczy Nomos.

Chałasiński, J. (1976). Polonia amerykańska. W: W.I. Thomas, F. Znaniecki, Chłop polski w Europie i Ameryce, t. 1 (ss. 7-29). Warszawa: Ludowa Spółdzielnia Wydawnicza.

Czyżewski, M. (1992). Uwagi o badaniach biograficznych. W: L. Wojtczak (red.), Bunty i służebności uczonego: profesor Józef Chałasiński (ss. 93-100). Łódź: Wydawnictwo Uniwersytetu Łódzkiego.

Dulczewski, Z. (1975). Florian Znaniecki jako twórca metody autobiograficznej w socjologii. W: A. Kwilecki (red.), Florian Znaniecki i jego rola w socjologii (ss. 75-88). Poznań: Wydawnictwo Naukowe Uniwersytetu im. Adama Mickiewicza w Poznaniu.

Hałas, E. (1983). Floriana Znanieckiego koncepcja definicji sytuacji a interpretacyjny paradygmat socjologii, Studia Socjologiczne, 1, 33-43.

Helling, I. (1990). Metoda badań biograficznych. W: J. Włodarek, M. Ziółkowski (red.), Metoda biograficzna w socjologii (ss. 13-37). Warszawa-Poznań: Państwowe Wydawnictwo Naukowe.

Kaźmierska, K. (2018). Doing Biographical Research: Ethical Concerns in Changing Social Contexts. Polish Sociological Review, 3, 393-411.

Merrill, B., West, L. (2009). Using Biographical Methods in Social Research. London: Sage.

Nachalnik, U. (1989). Życiorys własny przestępcy, Łódź: Wydawnictwo Łódzkie.

Schütz, A. (1985). Światły obywatel. Esej o społecznym zróżnicowaniu wiedzy. Literatura na Świecie 2, 269-284.

Schütze, F. (2012). Trajektorie cierpienia jako przedmiot badań socjologii interpretatywnej. W: K. Kaźmierska (red.), Metoda biograficzna w socjologii. Antologia tekstów (ss. 415-458). Kraków: Zakład Wydawniczy Nomos.

Shaw, C.R. (1930). The Jack-Roller: A Delinquent boy's own story, Chicago: University of Chicago Press.

Shaw, C.R., Moore, M.E. (1931). The Natural History of Delinquent Career, Chicago: University of Chicago Press.

Szacki, J. (2002). Historia myśli socjologicznej, t. 2. Warszawa: Wydawnictwo Naukowe PWN.

Szczepański, J. (1976). Dzieło W. I. Thomasa i F. Znanieckiego w rozwoju socjologii. W: W.I. Thomas, F. Znaniecki, Chłop polski w Europie i Ameryce, t. 1 (ss. 30-38). Warszawa: Ludowa Spółdzielnia Wydawnicza.

Thomas, W.I. (1923). The Unadjusted Girl with Cases and Standpoint for Behavior Analysis, Criminal Science Monographs, No. 4.

Thomas, W.I., Znaniecki, F. (1976). Chłop polski w Europie i Ameryce, t. 1-5. Warszawa: Ludowa Spółdzielnia Wydawnicza.

Thomas, W.I., Znaniecki, F. (1918-1920). The Polish Peasant in Europe and America, vol. 1-4, Boston: Richard G. Badger. 